Jarosław URBANIAK

Uniwersytet im. Adama Mickiewicza, Poznań

\title{
Europeizacja nadzoru bankowego w Polsce
}

\section{Wprowadzenie}

Wadrzędnym celem wynikającym bezpośrednio z czynności nadzor1 czych w sektorze bankowym, jest eliminowanie zagrożeń będących efektem narażania banków na zbyt duże ryzyko finansowe. Wynikiem pośrednim takich działań jest zabezpieczenie interesu klientów, którzy powierzają swoje oszczędności instytucjom bankowym. Kluczowe w tym procesie jest przede wszystkim tworzenie transparentnych zasad dotyczących funkcjonowania nadzoru bankowego oraz konsekwentne ich przestrzeganie. Zapewnienie bezpieczeństwa i prawidłowości w systemach bankowych, jest możliwe poprzez przestrzeganie przez instytucje bankowe zarówno zasad zewnętrznych (głównie powszechnie obowiązujących przepisów prawa), jak i wewnętrznych oraz dbania o zapewnienie równej konkurencji na rynku finansowym.

Nadzór bankowy jest formą interwencjonizmu państwowego, w której to państwo wyraża chęć sprawowania pieczy nad bezpieczeństwem i prawidłowością funkcjonowania systemu bankowego ${ }^{1}$. Instytucja nadzorcza monituje i ocenia działanie mechanizmów rynkowych oraz zachowanie uczestników rynku finansowego, reagując na pojawiające się nieprawidłowości. Nadzór bankowy posiada cechy tożsame dla samodzielnej instytucji prawnej, która w całości podlega zasadzie legalizmu. Zgodnie z tą definicją wszystkie instytucje powiązane w sposób bezpośredni z nadzorem, są upoważnione do wnikania w działalność bankową tylko i wyłącznie w przypadkach określonych w przepisach prawnych.

Stabilność systemu bankowego jest priorytetem, który nie tylko odnosi się do dobra klientów, ale także wpływa wprost na tworzenie odpowiednich warunków do zapewnienia skutecznej polityki pieniężnej, która reguluje podaż na rynku finansowym. Mając na celu realizację polityki pieniężnej Narodowy Bank Polski wykorzystywać może narzędzia ma-

1 E. Fojcik-Mastalska, Prawo bankowe, Wrocław 2009, s. 141. 
jące charakter zarówno rynkowy, jak i administracyjny². Przykładem mogą być nakładane klientom pułapy kredytowe, mające na celu ograniczenie udzielanych im kredytów.

Osiagnięcie celu, jakim jest prawidłowo funkcjonujący mechanizm nadzoru bankowego, jest możliwe poprzez realizację czterech podstawowych funkcji:

- Funkcja regulacyjna - określa podstawowe zasady, na których opiera się funkcjonowanie banków, poprzez ustalanie minimalnych norm związanych z zapewnieniem bezpieczeństwa w ich działalności. Do ustalenia tych norm niezbędne są prawidłowo określone fundusze własne $^{3}$, stanowiące zabezpieczenie, w przypadku konieczności zminimalizowania strat wynikających z funkcjonowania banku. Omawiane regulacje zgodnie z art. 128 ustawy Prawo bankowe, dotyczą głównie wymogów kapitałowych, muszą one być także adekwatne kapitałowo ${ }^{4}$.

- Funkcja licencyjna - dotyczy przepisów i norm odnoszących się do tworzenia, organizowania i regulowania struktur banków, zarówno ich przedstawicielstw, jak i oddziałów. W procesie licencjonowania wydawana jest zgoda na utworzenie banku, rozpoczęcie przez niego działalności, zmiany w statucie oraz weryfikowani są właściciele banku oraz jego władze ${ }^{5}$. Funkcja ta także w sposób bezpośredni odnosi się do gromadzonego kapitału, niezbędnego do działalności bankowej, aby zapewniał on poczucie zaufania publicznego.

- Funkcja kontrolno-administracyjna - realizowana jest poprzez stały wgląd w ewentualne zagrożenia w funkcjonowaniu banków. Banki zobowiązane są do prowadzenia bieżących sprawozdań, które stanowią bazę wiedzy na temat aktualnej sytuacji wewnątrz systemu, równolegle tworzonej w wyniku wdrażania polityki kontroli z zewnątrz, realizowanej poprzez doraźne inspekcje pracowników instytucji nadzoru. Kontrola ma na celu zweryfikowanie poprawności i porównanie sytuacji faktycznie, aktualnie istniejącej w instytucji bankowej, do tej pierwotnie pożądanej.

2 W. Jaworski, Banki, rynek, operacje, polityka, Warszawa 1998, s. 63.

3 Rezerwy są tworzone na pokrycie negatywnych skutków wynikających z ryzyka obecnego przy działalności bankowej. Zgodnie z art. 130 ust. 1 ustawy Prawo bankowe, banki są zobowiązane do tworzenia rezerw na ryzyko ogólne, które w efekcie stanowić mają zabezpieczenie dla ryzyka związanego $\mathrm{z}$ działalnością bankową.

4 E. Fojcik-Mastalska, Prawo..., op. cit., s. 143.

5 D. Daniluk, S. Niemierka, Nadzór bankowy w Polsce, „Polski System Bankowy. Stan i Perspektywy" 2005, nr 9, s. 7. 
- Funkcja dyscyplinująca - polega na podejmowaniu działań zapobiegawczych lub naprawczych w stosunku do instytucji bankowych. W określonych przez prawo sytuacjach nadzór może stosować środki nadzoru administracyjnego, w postaci sankcji i zaleceń, w stosunku do instytucji jako takiej, a także do jej organów i osób odpowiedzialnych za nieprawidłowości. Formą naprawczą są środki naprawczo-likwidacyjne, które ze względu na skutki z nich wynikające - albo podtrzymują byt prawny podmiotu bankowego, jednakże modyfikując jego sytuację finansową - albo wpływają bezpośrednio na jego upadłość, realizując równolegle zasadę zapewnienia maksymalnego bezpieczeństwa klientów.

\section{Ksztaltowanie się podstaw nadzoru bankowego (1989-1997)}

Bezpośredni wpływ na kształtowanie się podstaw nadzoru bankowego, miała transformacja systemu politycznego, społecznego, a także gospodarczego, zapoczątkowana w 1989 roku. Wprowadzone wtedy zmiany, głównie w zakresie ustroju gospodarczego przyczyniły się do dynamicznego rozwoju sektora bankowego.

Pierwszym symptomem transformacji sektora bankowego było uchwalenie przez Sejm dwóch ustaw - ustawy Prawo Bankowe ${ }^{6}$, a także ustawy o Narodowym Banku Polskim ${ }^{7}$. Obie regulacje prawne przyczyniły się do zmiany formy sprawowania nadzoru nad rynkiem finansowym ${ }^{8}$. Pierwsza z wymienionych ustaw regulowała kwestie zapewnienia bezpieczeństwa środków i lokat gromadzonych w bankach, prawidłowej działalności banków w związku z ustawą Prawo Bankowe oraz odpowiedniej procedury stosowanej w przypadku kontaktów wynikających z działalności bankowej, z osobami fizycznymi czy prawnymi ${ }^{10}$. Druga z kolei ustawa tworzyła dwupoziomowy system bankowy składający się z banku centralnego oraz banków komercyjnych, przy czym funkcje banku centralnego powierzała Narodowemu Bankowi Polskiemu.

6 Ustawa z dnia 31 stycznia 1989 r. Prawo bankowe, Dz. U. 1989, Nr 4, poz. 21.

7 Ustawa z dnia 31 stycznia 1989 r. o Narodowym Banku Polskim, Dz. U. 1989, $\mathrm{Nr}$ 4, poz. 22.

8 Szerzej zob.: Prawo bankowe. Komentarz, red. W. Góralczyk, Warszawa 1999, s. $476-509$.

9 Ustawa Prawo bankowe, art. 133, ust. 1.

10 Ustawa Prawo bankowe, art. 100, ust. 3. 
NBP w ramach szerokiego zadania kształtowania polityki pieniężnej, powierzono także całkowity nadzór nad wszelkiego rodzaju działalnością bankową ${ }^{11}$. Dla wykonywania tej funkcji, w maju 1989 roku, w strukturze NBP utworzono wyspecjalizowaną komórkę organizacyjną - Departament Nadzoru Bankowego, który rok później zmienił nazwę na Generalny Inspektorat Nadzoru Bankowego. Głównym zadaniem tej jednostki, było zapewnienie odpowiednich warunków, niezbędnych do osiągnięcia bezpieczeństwa środków finansowych, które zostały powierzone instytucjom bankowym.

Istotnym postępem w procesie tworzenia się systemu nadzoru bankowego było uchwalenie ustawy z dnia 19 października 1991 roku o badaniu i ogtaszaniu sprawozdań finansowych oraz biegtych rewidentach i ich samorzadzie ${ }^{12}$. Zgodnie z uregulowaniami tej ustawy, która weszła w życie z dniem 1 stycznia 1992 roku, wszystkie wyniki raportów finansowych były podawane do publicznej wiadomości i obowiązkowo publikowane, co umożliwiało podmiotom zewnętrznym (w tym klientom) ocenę banków na podstawie zweryfikowanego stanu faktycznego.

W okresie pierwszych trzech lat transformacji systemu gospodarczego w Polsce udało się stworzyć podstawy systemu nadzoru bankowego. System ten był jednak dalece niedoskonały. W wyniku stosowania błędnych metod egzekwowania nadzoru bankowego, braku doświadczenia, ograniczonych możliwości kadrowych nadzór nie był sprawowany w sposób wystarczający ${ }^{13}$. W latach 1992-1993 nasilił się kryzys na rynku bankowym. Skupiono się wówczas na restrukturyzacji instytucji, które były narażone na niebezpieczeństwo utraty płynności finansowej. Aby móc temu zapobiec Narodowy Bank Polski działał na rzecz restrukturyzacji banków poprzez opracowywanie na ich rzecz planów naprawczych.

Ważnym etapem kształtowania się systemu nadzoru bankowego było uchwalenie ustawy z dnia 14 grudnia 1994 roku o Bankowym Funduszu Gwarancyjnym $^{14}$. Celem wprowadzenia ustawy było niedopuszczenie do załamania finansowego banków prywatnych oraz zwiększenie zaufania klientów do systemu bankowego. Wprawdzie ustawa przyjęła pasywny

11 A. Mikos, Ustrojowa pozycja Banku Centralnego w Polsce, Warszawa 2006, s. 107.

12 Ustawa z dnia 19 października 1991 r. o badaniu i ogłaszaniu sprawozdań finansowych oraz biegłych rewidentach i ich samorzadzie, Dz. U. 1991, Nr 111, poz. 480.

13 D. Daniluk, S. Niemierka, Nadzór bankowy..., op. cit., s. 9.

14 Ustawa z dnia 14 grudnia 1994 r. o Bankowym Funduszu Gwarancyjnym, Dz. U. 1995, $\mathrm{Nr} 4$, poz. 18. 
model gwarancyjny, polegający jedynie na stosowaniu instrumentów pomocniczych i bierną ochronę depozytów, to jednak wprowadzone rozwiązania były kolejnym krokiem w stabilizacji polskiego systemu bankowego.

W kolejnych latach NBP starał się wpłynąć na eliminację wszelkich barier stojących na przeszkodzie w wykonywaniu nadzoru bankowego. Wiązało się to ze stałym analizowaniem sytuacji sektora bankowego, przy jednoczesnym weryfikowaniu zgodności działalności bankowej z obowiązującymi normami prawnymi. Wdrażano w tym przypadku metodę bieżącego monitoringu, która wiązała się z koniecznością zastosowania określonych norm i zakresów sprawozdawczości, praktykowanych oraz wdrażanych w państwach Unii Europejskiej. NBP, korzystając z doświadczeń państw Unii Europejskiej opracował zalecenia, przekazywane instytucjom bankowym, odnoszące się do tematyki związanej z zarządzaniem ryzykiem wynikającym ze stosowanych systemów informatycznych, a także z zagrożeniem wynikającym z praktykowania przez banki transakcji pochodnych.

Chęć stworzenia nowoczesnego systemu nadzoru bankowego wiązała się z poprawą bezpieczeństwa finansowego instytucji bankowych, zwiększeniem zaufania publicznego, umożliwienia zastosowania rozwiązań i metod, wdrażanych w państwach Unii Europejskiej. Polityka ta, była konsekwencją wejścia w życie 1 lutego 1994 roku Układu Europejskiego, który obligował Polskę do dostosowania zasad obowiązujących w prawie bankowym, do standardów unijnych ${ }^{15}$.

\section{Komisja Nadzoru Bankowego}

Najważniejszym wydarzeniem, zamykającym jednocześnie proces kształtowania się podstaw nadzoru bankowego było uchwalenie 29 sierpnia 1997 roku ustawy Prawo bankowe ${ }^{16}$ oraz ustawy o Narodowym Banku Polskim ${ }^{17}$. Najważniejszą i zarazem podstawową zmianą dotyczącą bez-

15 Układ Europejski ustanawiajacy stowarzyszenie między Rzeczpospolita Polska a Wspólnotami Europejskimi i ich państwami członkowskimi, sporzqdzony w Brukseli dnia 16 grudnia 1991 r., Dz. U. 1994, Nr 11, poz. 38.

16 Ustawa z dnia 29 sierpnia 1997 r. Prawo Bankowe, Dz. U. 1997, Nr 140, poz. 939.

17 Ustawa z dnia 29 sierpnia 1997 r. o Narodowym Banku Polskim, Dz. U. 1997, $\mathrm{Nr} 140$, poz. 938 . 
pośrednio sprawowania nadzoru, było powołanie wyspecjalizowanego organu nadzoru bankowego - Komisji Nadzoru Bankowego.

Komisja Nadzoru Bankowego przejęła wcześniejsze kompetencje Narodowego Banku Polskiego w zakresie nadzoru nad sektorem bankowym. Komisja była organem kolegialnym, niezależnym od NBP, choć powiązanym z nim osobą przewodniczącego, którym był z mocy prawa prezes $\mathrm{NBP}^{18}$. Obok prezesa NBP w skład Komisji wchodzili: minister finansów (lub wyznaczony przez niego sekretarz lub podsekretarz stanu) - jako wiceprzewodniczący, przedstawiciel ministra finansów, prezes Bankowego Funduszu Gwarancyjnego, przewodniczący Komisji Papierów Wartościowych, przedstawiciel Prezydenta Rzeczypospolitej Polskiej oraz Generalny Inspektor Nadzoru Bankowego - będący organem wykonawczym Komisji, odpowiedzialnym za koordynację jej pracy ${ }^{19}$. Dodatkowo w każdym z posiedzeń Komisji Nadzoru Bankowego uczestniczył przedstawiciel Związku Banków Polskich ${ }^{20}$.

Komisja Nadzoru Bankowego upoważniona była do wydawania zezwoleń, upoważnień, wydawanych w formie uchwał, posiadających moc ostatecznych i wiążących decyzji administracyjnych. Komisja zobowiązana była, na podstawie przepisów zawartych w ustawie Prawo bankowe, do realizacji szeregu zadań, których sposób wykonania sformułowany został ściśle także w omawianej ustawie. Przede wszystkim skupiać się ona miała na nadzorowaniu działalności banków, pod względem przestrzegania ustaw i statutu, określeniu prawideł funkcjonowania banków, przy jednoczesnym zapewnianiu bezpieczeństwa środkom zgromadzonym przez klientów na rachunkach bankowych, jak i opiniowania reguł nadzoru i regulowania kwestii ich przestrzegania. Komisja Nadzoru Bankowego upoważniona była do sporządzania okresowych ocen działalności banków, pod kątem stanu ekonomicznego, jak i związanej z tym polityki ekonomicznej, która warunkowała ich rozwój. Przedmiotem analiz było analizowanie wypłacalności ${ }^{21}$ i płynności płatniczej, ocena sytuacji finansowej, weryfikowania zabezpieczeń i terminowości spłat debetów, gwarancji bankowych, jak i badanie zgodności stosowania przepisów

18 W. Kwaśniak, Jeszcze nie teraz, „Gazeta Bankowa” 2001, nr 7, s. 14.

19 A. Mikos, Ustrojowa pozycja..., op. cit., Warszawa 2006, s. 118.

20 W. Szostak, M. Piwnicka, Nadzór Bankowy w Rzeczypospolitej Polskiej, Stowarzyszenie Ekonomistów Rolnictwa i Agrobiznesu, „Roczniki Naukowe”, t. VIII, z. 4, s. 330 .

21 A. M. Jurkowska, Prawo bankowe Unii Europejskiej, Bydgoszcz 2003, s. 64. 
prawnych zawartych w ustawie Prawo bankowe, w odniesieniu do oprocentowania kredytów ${ }^{22}$. Ogólnie rzecz biorąc Komisja odpowiadała za wdrażanie polityki, związanej ze sprawowaniem funkcji regulacyjnej, licencyjnej, kontrolnej, jak i naprawczo-likwidacyjnej. Komisja Nadzoru Bankowego przejęła zadanie zastosowania wszystkich podstawowych funkcji wcześniej realizowanych poprzez bank centralny, a nowa formuła instytucjonalizacji nadzoru, polegająca na jego wydzieleniu ze struktur NBP, stanowiła krok w kierunku rozwiązań przyszłościowych ${ }^{23}$.

Funkcjonowanie KNB zdeterminowane zostało przez dwa istotne procesy. Pierwszym z nich były fuzje w sektorze bankowym, w wyniku czego skonsolidowano 29 banków komercyjnych. Drugim czynnikiem mającym bezpośredni wpływ na funkcjonowanie polskiego systemu bankowego, były procesy dostosowawcze sfery regulacyjnej, systemowej, jak i jakościowej związanej z działalnością banków, do standardów stosowanych w Unii Europejskiej ${ }^{24}$.

\section{Dostosowanie nadzoru bankowego do wymogów Unii Europejskiej (1998-2004)}

Pierwsze lata działalności KNB, to okres jej dużej aktywności nadzorczej, szczególnie w zakresie wdrażania postępowań naprawczych w stosunku do zagrożonych banków. W dwóch przypadkach KNB zdecydowała się na zawieszenie działalności banków i skierowanie wniosków o ogłoszenie upadłości. Stało się tak w przypadku Banku Staropolskiego S.A., jak i jednego z banków spółdzielczych ${ }^{25}$.

W tym samym czasie zaczęto wdrażać proces dostosowywania polskiego systemu bankowego do wymogów prawa europejskiego. Ważnym krokiem w procesie harmonizacji polskiego prawa bankowego z tzw. acquis communautaire ${ }^{26} \mathrm{~W}$ dziedzinie bankowości była gruntowna nowe-

22 W. Szostak, M. Piwnicka, Nadzór Bankowy..., op. cit., s. 329.

23 W. Baka, Bankowość centralna. Funkcje. Metody. Organizacja, Warszawa 2001, s. 129 .

24 C. Kosikowski, Problemy harmonizacji polskiego prawa finansowego z prawem Wspólnot Europejskich, „Państwo i Prawo” 1996, nr 4-5, s. 77.

25 D. Daniluk, S. Niemierka, Nadzór bankowy..., op. cit., s. 16.

26 Acquis communautaire - dorobek prawny Unii Europejskiej, obejmujący wszystkie akty prawne prawa pierwotnego (traktaty założycielskie i akcesyjne oraz umowy międzynarodowe) i wtórnego (rozporządzenia, dyrektywy), a także zasady 
lizacja ustawy Prawo Bankowe uchwalona w lipcu 2001 r. $^{27}$ Ustawa wprowadzająca wiele zmian systemowych, takich jak:

- licencjonowanie instytucji kredytowych i oddziałów instytucji kredytowych w momencie uzyskania członkostwa w UE;

- stworzenie nadzoru skonsolidowanego będącego wynikiem skonsolidowanego sprawozdania finansowego ${ }^{28}$;

- szczegółowe uregulowanie zasad adekwatności kapitałowej;

- regulacje dotyczące norm ostrożnościowych odnoszących się do koncentracji wierzytelności i rachunku funduszy własnych banków ${ }^{29}$.

Wprowadzone w drodze nowelizacji ustawy Prawo bankowe zmiany do systemu nadzoru bankowego pozwoliły osiagnać pełną harmonizację zarówno rozwiązań prawnych, jak i standardów nadzorczych obowiązujących w Polsce z rozwiązaniami stosowanymi w Unii Europejskiej ${ }^{30}$.

Ostatnią modyfikacją nadzoru bankowego z punktu widzenia członkostwa w Unii Europejskiej była nowelizacja ustawy z dnia 1 kwietnia 2004 roku o zmianie ustawy Prawo bankowe oraz o zmianie niektórych ustaw $^{31}$. Głównym zadaniem nowelizacji było stworzenie porównywalnych warunków działania dla banków w Polsce i w UE. Wprowadzono szereg nowych instrumentów finansowych, takich jak: outsourcing, sekurytyzacja wierzytelności bankowych czy cash pooling. Obok tego uregulowano zasady tajemnicy bankowej, pośrednictwa bankowego, prowadzenia rachunków bankowych, a przede wszystkim sprecyzowano i rozszerzono zadania KNB w docelowym modelu systemu bankowego. Równolegle do zmian ustawowych KNB starała się udoskonalać instrumenty służące bieżącej kontroli sektora bankowego. Przykładem takich działań było wprowadzenie inspekcyjnych i analitycznych systemów oceny punktowej banków, które na bieżąco monitorowały jakość prowadzonej przez nie działalności ${ }^{32}$.

prawne, orzecznictwo Europejskiego Trybunału Sprawiedliwości, jak i Sądu Pierwszej Instancji.

27 Ustawa z dnia 23 sierpnia 2001 roku, o zmianie ustawy Prawo bankowe oraz o zmianie innych ustaw, Dz. U. 2001, Nr 111, poz. 1195.

28 Roz. 11 b - Nadzór Skonsolidowany.

29 D. Daniluk, S. Niemierka, Nadzór bankowy..., op. cit., s. 17.

30 Z. Czachór, A. Graś, Vademecum Europa od A do Z, Warszawa 2006, s. 36.

31 Ustawa z dnia 1 kwietnia 2004 r. o zmianie ustawy Prawo bankowe oraz o zmianie niektórych ustaw, Dz. U. 2004, Nr 91, poz. 870.

32 D. Daniluk, S. Niemierka, Nadzór bankowy..., op. cit., s. 17. 
Podsumowując działania przeprowadzone w latach 1998-2004 w celu dostosowania polskiego systemu nadzoru bankowego do członkostwa Polski w UE, należy stwierdzić, że przyjęte rozwiązania instytucjonalne, a także szczegółowe uregulowania prawne doprowadziły do zbudowania nowoczesnego, odpowiadającego standardom europejskim modelu nadzoru.

\section{Polski nadzór bankowy w sytuacji członkowstwa w Unii Europejskiej (od 2004 r.)}

Od 1 maja 2004 roku Rzeczpospolita Polska jest członkiem Unii Europejskiej. Członkostwo w UE stworzyło nową sytuację w działalności nadzoru bankowego. Po zakończonym sukcesem procesie harmonizacji polskich rozwiązań nadzorczych, rozpoczął się proces jego funkcjonowania w nowych realiach regulowanych przez zasady jednolitego europejskiego rynku finansowego ${ }^{33}$.

Polski nadzór bankowy, podobnie jak odpowiadające mu instytucje i organy w innych państwach członkowskich, posiada znaczą swobodę w zakresie stosowania metod i instrumentów nadzoru na rynku bankowym. Szczególnie dotyczy to tych sfer, które do tej pory nie zostały uregulowane przepisami unijnymi. Zasadniczym segmentem systemu bankowego są jednak te sfery, które związane są ze wspólnym rynkiem finansowym i w efekcie wymagają współpracy i koordynacji w ramach UE. W tym kontekście bardzo istotnym elementem, stanowiącym kolejne wyzwanie dla polskiego sektora bankowego, było dostosowanie rynku do wprowadzenia Bazylejskiej Nowej Umowy Kapitałowej. Jednakże ocena wpływu Nowej Bazylejskiej Umowy Kapitałowej na bezpieczeństwo banków, w tym na bezpieczeństwo polskiego sektora bankowego możliwa będzie dopiero po dłuższym okresie jej obowiązywania ${ }^{34}$.

Istotnym z punktu widzenia kształtu nadzoru bankowego są rozwiązania zawarte w ustawie z dnia 15 kwietnia 2005 roku, o nadzorze uzupełniającym nad instytucjami kredytowymi, zakładami ubezpieczeń, zakładami

33 Zob. szerzej: P. Zapadka, S. Niemierka, Charakterystyka europejskiego systemu bankowego - zagadnienia instytucjonalno-prawne. System prawny oraz organizacja rynku finansowego w Unii Europejskiej, „Bank i Kredyt” 2003, nr 10.

34 Nowa Umowa Kapitałowa Bazylejskiego Komitetu Nadzoru Bankowego - Konsekwencje dla gospodarki i sektora bankowego w Polsce, red. R. Wierzba, M. Iwanicz-Drozdowska, B. Lepczyński, Gdańsk 2004, s. 85. 
reasekuracji i firmami inwestycyjnymi wchodzącymi w skład konglomeratu finansowego ${ }^{35}$, umożliwiły stworzenie w Polsce warunków do podejmowania przez organy nadzorcze odpowiednich działań w stosunku do konglomeratów działających na rynku bankowym. Miały one na celu głównie przyczynienie się do przyspieszenia tempa rozwoju i ewolucji w polskim systemie bankowym.

Od 1 stycznia 2008 roku, sprawowanie nadzoru bankowego powierzone zostało Komisji Nadzoru Finansowego, powołanej na mocy ustawy $\mathrm{z}$ dnia 21 lipca 2006 roku o nadzorze nad rynkiem finansowym ${ }^{36}$. Ustawa przekazała funkcję nadzoru nad rynkiem bankowym, sprawowaną dotychczas poprzez Komisję Nadzoru Bankowego - Komisji Nadzoru Finansowego, która jest organem właściwym w sprawach nadzoru nad rynkiem finansowym. Funkcja nadzorcza nad działalnością Komisji powierzona została Prezesowi Rady Ministrów. KNF zobowiązana została do przedkładania corocznych sprawozdań z własnej działalności. Główną przyczyną, dla której zdecydowano się na modyfikację systemu nadzorczego, była próba stworzenia idealnych warunków do wdrażania ,nadzoru zintegrowanego"37. Komisja Nadzoru Finansowego funkcjonuje na kilku szczeblach, koncentrujących się kolejno na nadzorze ubezpieczeniowym, bankowym, emerytalnym, rynkiem kapitałowym, instytucjami pieniądza elektronicznego, jak i nadzorze uzupełniającym.

Do głównych zadań realizowanych poprzez KNF, należy uczestniczenie $\mathrm{w}$ tworzeniu projektów aktów prawnych dotyczących nadzoru nad rynkiem finansowym, realizowanie zadań edukacyjnych i informacyjnych w ramach funkcjonowania rynku finansowego, podejmowanie działań mających istotny wpływ na rozwój konkurencyjności rynku finansowego, jak i dbanie o jego prawidłowe funkcjonowanie.

Komisja Nadzoru Finansowego stwarza możliwości polubownego rozwiązywania sporów i konfliktów pomiędzy uczestnikami rynku finan-

35 Ustawa z dnia 15 kwietnia 2005 roku o nadzorze uzupetniajacym nad instytucjami kredytowymi, zakładami ubezpieczeń, zakładami reasekuracji i firmami inwestycyjnymi wchodzacymi w skład konglomeratu finansowego, Dz. U. 2005, Nr 83, poz. 719. Ustawa wprowadza do polskiego prawa postanowienia dyrektywy 2002/87/WE Parlamentu Europejskiego i Rady.

36 Ustawa z dnia 21 lipca 2006 r. o nadzorze nad rynkiem finansowym, Dz. U. 2006, Nr 157, poz. 1119.

${ }^{37}$ K. Ostrowska, M. Rzemek, Prezes będzie miat wszystko: Projekt ustawy, powstanie jeden nadzór nad całym rynkiem finansowym, „Rzeczpospolita”, 13.01.2005, nr 11 , s. B1. 
sowego, poprzez równoległe funkcjonowanie sądu polubownego, mającego na celu rozstrzyganie tychże sporów, związanych z wzajemnymi stosunkami pomiędzy uczestnikami rynku finansowego wynikającymi z umów.

W zakresie bankowym działalność nadzorcza koncentruje się na: badaniu zgodności udzielanych kredytów, poręczeń, pożyczek pieniężnych, gwarancji bankowych oraz papierów wartościowych z obowiązującymi w tym zakresie przepisami; regulacją dotyczącą terminowości spłaty kredytów i pożyczek pieniężnych; oceną szacowania, utrzymywania i przeglądu posiadanego kapitału; badaniu jakości administrowania i zarządzania bankiem; weryfikowaniu poprawności realizowania zadania, jakim jest przestrzeganie ściśle określonych norm dopuszczalnego ryzyka, zarządzania tym ryzykiem. Sam system identyfikacji ryzyka oraz sporządzania raportów i sprawozdań o ryzyku, musi być dostosowany do skali działalności i rodzaju banku.

Wszystkie te działania wiążą się z koniecznością stosowania stałego i nieprzerwalnego nadzoru nad rynkiem finansowym, w postaci skoordynowanego i rozbudowanego systemu współpracy. Bezpieczeństwo systemu finansowego, zależeć może w dużym stopniu od usprawnienia nadzoru, w postaci zwiększenia współdziałania na poszczególnych szczeblach systemu, w wyniku wymiany wspólnych doświadczeń, czy też gromadzenia bazy pomysłów i rozwiązań ${ }^{38}$.

\section{Na drodze do Europejskiego Nadzoru Bankowego}

Doświadczenia związane z kryzysem finansowym ujawniły istotne braki w nadzorze finansowym, w tym głównie bankowym. Obowiązujące rozwiązania w zakresie nadzoru nie były w stanie zapobiec sytuacjom kryzysowym, zapewnić zarządzania nimi oraz rozwiązać problemów z nich wynikających. Nadzór oparty na modelach krajowych nie nadąża za rzeczywistością, w której europejskie rynki finansowe są zintegrowane i połączone, a liczne przedsiębiorstwa finansowe działają na szczeblu transgranicznym. Kryzys obnażył również poważne niedociągnięcia w za-

38 M. Iwanicz-Drozdowska, Determinanty bezpieczeństwa banków w świetle analizy wybranych kryzysów bankowych, „Monografie i Opracowania” 479, Warszawa 2000, s. 204. 
kresie spójności i koordynacji działań oraz wzajemnej współpracy organów nadzorczych ${ }^{39}$.

W listopadzie 2008 roku Komisja Europejska zleciła grupie ekspertów pod przewodnictwem J. de Larosière'a opracowanie raportu dotyczącego stanu i perspektyw europejskiego systemu nadzoru finansowego. W dniu 25 lutego 2009 roku przedstawiono raport końcowy komisji de Larosière'a. Raport odwołuje się do nowej wizji europejskiego systemu nadzoru finansowego, składającego się z rady oceny ryzyka oraz organów nadzorujących banki, ubezpieczycieli i giełdy $\mathrm{w} \mathrm{UE}^{40}$. Znajdują się $\mathrm{w}$ nim główne propozycje wzmocnienia współpracy i koordynacji pomiędzy krajowymi organami nadzoru. Zdaniem autorów raportu wyjściem z sytuacji kryzysowej jest stworzenie nowych, europejskich organów nadzoru oraz - po raz pierwszy - podmiotu na szczeblu europejskim, nadzorującego zagrożenia, na które narażony jest system finansowy jako całość.

Przygotowany na wiosenny szczyt UE Komunikat Komisji Europejskiej „Realizacja europejskiego planu naprawy” z dnia 4 marca 2009 r. wyraził wyraźne poparcie Komisji dla głównych zaleceń raportu de Larosière’a, Komunikat określił dokładny plan działania na rzecz reformy sposobu regulacji i nadzoru rynków finansowych ${ }^{41}$.

$\mathrm{W}$ celu usprawnienia prowadzenia równoległych prac w zakresie nadzoru, Komisja podjęła decyzję o przyspieszeniu harmonogramu wdrożenia reformy nadzoru finansowego w Unii Europejskiej. Najbardziej wyraźnie podczas rozmów na forum Rady Europejskiej, Rady UE i Parlamentu Europejskiego, zarysowała się idea szerokiego konsensusu, w przypadku potrzeby reformy oraz celów, do których zgodnie z raportem de Larosière'a należy dążyć. Ważny krok w kierunku nowego europejskiego wymiaru nadzoru finansowego stanowi właśnie omawiany komunikat ${ }^{42}$. Rada Europejska jest w nim wzywana przez Komisję do zatwierdzenia nowej struktury, zgodnie z zamieszczonymi w komunikacie wnioskami i postanowieniami.

39 Zob.: Europejski Nadzór Finansowy, Komunikat Komisji, COM (2009), 252 wersja ostateczna, Bruksela, 27.05.2009, s. 2.

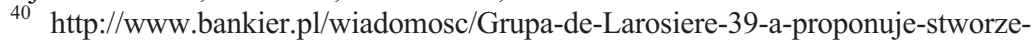
nie-europejskiego-systemu-nadzoru-finansowego-1913873.html.

41 Komunikat Komisji Wspólnot Europejskich, Europejski nadzór finansowy, Bruksela, dnia 27.5.2009.

42 Komunikat Komisji z dnia 4 marca 2009 r. na wiosenny szczyt Rady Europejskiej zatytułowany Realizacja europejskiego planu naprawy, COM(2009) 114 wersja ostateczna. 
Zapowiedzi przedstawione w omawianym komunikacie, znalazły swoje odzwierciedlenie w praktyce. Komisja zaproponowała bowiem, aby nowe, lepsze ramy nadzoru finansowego w wymiarze europejskim, składały się z dwóch filarów. Pierwszy - Europejska Rada ds. Ryzyka Systemowego $(\text { ERRS })^{43}$ oraz drugi - Europejski System Organów Nadzoru Finansowego (ESONF), w skład którego wchodzą przedstawiciele krajowych organów nadzoru finansowego, co stworzy warunki do centralizacji wybranych zadań na poziomie europejskim. Głównym celem zaproponowanych reform, ma być harmonizacja praktyk w dziedzinie nadzoru, jak i ujednolicenie przepisów z nim związanych. Efektem tych działań ma być zwiększone zaufanie krajowych organów nadzorczych, a co się z tym wiąże, bardziej skuteczne przeciwdziałanie zagrożeniom transgranicznym ${ }^{44}$. Ewentualne wdrażanie nowego systemu nadzoru finansowego na poziomie europejskim, musi odbywać się pod nadzorem organów unijnych ${ }^{45}$.

W tym samym kierunku podążają propozycje przedstawione przez prezydencję Rady Unii Europejskiej wyrażoną w konkluzji ogłoszonej w Brukseli 18-19 czerwca 2009 roku. Rada Europejska potwierdza w niej konieczność ustanowienia europejskiego systemu organów nadzoru finansowego, skupionego w nowych europejskich organach nadzorczych, czego głównym celem na być poprawa spójności i wzmocnienie nadzoru nad podmiotami mającymi charakter transgraniczny. Proponowanym wyjściem z tej sytuacji jest utworzenie kolegiów nadzorców i wdrożenie jednolitej księgi zasad nadzorczych, obejmującej swoim zasięgiem przestrzeń europejska, stosowanej bezwzględnie poprzez wszystkie instytucje finansowe na jednolitym rynku ${ }^{46}$.

\section{Summary}

Banking supervision is a form of state interventionism applied by this state to express its intention to exercise control over the safety and appropriate functioning of banking system. Membership of the EU has created a new situation in the operation of

43 Głównym jej zadaniem jest monitorowanie i ocena zagrożenia dla stabilności finansowej, wynikające z rozwoju sytuacji makroekonomicznej oraz sytuacji w ramach całego systemu finansowego.

44 Ibidem.

45 Ibidem.

46 Zob.: Konkluzje prezydencji Bruksela 18-19 czerwca 2009 r., Rada Europejska, 11225/2/09, Bruksela, 10 lipca 2009. 
banking supervision. After the process of harmonization of Polish supervisory solutions was successfully completed, the supervision started to operate under the new circumstances, regulated by the principles of the uniform European financial market. As of January 1, 2008, banking supervision has been vested with the Polish Financial Supervision Authority (KNF). The experience of financial crisis has revealed significant deficiencies in financial supervision, mainly banking supervision. Therefore, the European Commission has decided to accelerate the pace with which financial supervision in the European Union is implemented. 